\section{(A) Check for updates}

Cite this: Dalton Trans., 2020, 49 11605

Received 3rd June 2020 Accepted 23rd July 2020

DOI: $10.1039 / \mathrm{d} 0 \mathrm{dt} 01982 \mathrm{~h}$

rsc.li/dalton

\title{
Visible-NIR absorption spectroscopy study of the formation of ternary plutonyl(vi) carbonate complexes $\uparrow$
}

\author{
Yongheum Jo, ${ }^{a}$ Hye-Ryun $\mathrm{Cho}^{\mathrm{b}}$ and Jong-II Yun (D) *a
}

\begin{abstract}
We present the first experimental evidence for the ternary complexation of calcium and magnesium ions with plutonyl(vi)tricarbonate species in carbonate-containing aqueous solutions using visible-NIR spectrophotometric titration. Prior to studying the ternary plutonyl(vi) carbonate complexation, visible-NIR absorption spectral information of $\mathrm{PuO}_{2}\left(\mathrm{CO}_{3}\right)_{2}{ }^{2-}$ and $\mathrm{PuO}_{2}\left(\mathrm{CO}_{3}\right)_{3}{ }^{4-}$ was successfully obtained. $\mathrm{PuO}_{2}\left(\mathrm{CO}_{3}\right)_{2}{ }^{2-}$ has a prominent peak at $853 \mathrm{~nm}$ and its molar absorptivity was determined to be $\varepsilon_{853}, \mathrm{PuO}_{2}\left(\mathrm{CO}_{3}\right)_{2}^{2-}=49.0 \pm 4.2 \mathrm{M}^{-1} \cdot \mathrm{cm}^{-1}$. The spectrophotometric titration results by adding calcium or magnesium to the plutonyl(VI) carbonate system consisting of $\mathrm{PuO}_{2}\left(\mathrm{CO}_{3}\right)_{2}{ }^{2-}$ and $\mathrm{PuO}_{2}\left(\mathrm{CO}_{3}\right)_{3}{ }^{4-}$ indicate the formation of $\mathrm{CaPuO}_{2}\left(\mathrm{CO}_{3}\right)_{3}{ }^{2-}$ and $\mathrm{MgPuO}_{2}\left(\mathrm{CO}_{3}\right)_{3}{ }^{2-}$ complexes and provide the formation constants at $0.1 \mathrm{M} \mathrm{H} / \mathrm{NaClO}_{4}$ for $\mathrm{MPuO}_{2}\left(\mathrm{CO}_{3}\right)_{3}{ }^{2-}$ from $\mathrm{PuO}_{2}\left(\mathrm{CO}_{3}\right)_{3}{ }^{4-}$, $\log K=4.33 \pm 0.50$ and $2.58 \pm 0.18$ for $\mathrm{M}=\mathrm{Ca}^{2+}$ and $\mathrm{Mg}^{2+}$, respectively. In addition, the formation constants of $\mathrm{CaPuO}_{2}\left(\mathrm{CO}_{3}\right)_{3}{ }^{2-}$ and $\mathrm{MgPuO}_{2}\left(\mathrm{CO}_{3}\right)_{3}{ }^{2-}$ from $\mathrm{PuO}_{2}\left(\mathrm{CO}_{3}\right)_{3}{ }^{4-}$ at infinite dilution $\left(\log K^{\circ}\right)$ were proposed to be $6.05 \pm 0.50$ and $4.29 \pm 0.18$, respectively, based on the correction of ionic strength using the Davies equation. The absorption spectrum of the ternary plutonyl(vi) complexes of $\mathrm{CaPuO}_{2}\left(\mathrm{CO}_{3}\right)_{3}{ }^{2-}$ is similar to that of $\mathrm{PuO}_{2}\left(\mathrm{CO}_{3}\right)_{3}{ }^{4-}$ with the exception of a characteristic absorption peak at $808 \mathrm{~nm}$ $\left(\varepsilon_{808,} \mathrm{CaPuO}_{2}\left(\mathrm{CO}_{3}\right)_{3^{2-}}=42.9 \pm 1.6 \mathrm{M}^{-1} \cdot \mathrm{cm}^{-1}\right)$. According to the calculated aqueous plutonyl $(\mathrm{VI})$ speciation including the ternary plutonyl(VI) complexes, $\mathrm{CaPuO}_{2}\left(\mathrm{CO}_{3}\right)_{3}{ }^{2-}$ is considered the dominant $\mathrm{Pu}(\mathrm{VI})$ species under environmental conditions, and plutonyl(VI) may be more mobile than expected in previous assessments.
\end{abstract}

\section{Introduction}

Plutonium is generally produced during nuclear power generation and by nuclear weapons programmes and is one of the most strictly regulated elements in the world because of national security, nuclear proliferation, and radiological hazard concerns. Anthropogenic activities such as nuclear weapons testing, ${ }^{1}$ severe accidents in nuclear power plants, improper waste management, and disposal of legacy waste ${ }^{2}$ can cause plutonium contamination in the environment. The fate and transport of plutonium in the environment must be assessed for the remediation of polluted sites and nuclear waste management. ${ }^{3}$ However, it is very difficult to predict the

\footnotetext{
${ }^{a}$ Department of Nuclear and Quantum Engineering, KAIST, 291 Daehak-ro, Yuseong-gu, Daejeon 34141, Republic of Korea. E-mail: jiyun@kaist.ac.kr ${ }^{b}$ Nuclear Chemistry Research Team, Korea Atomic Energy Research Institute, 111 Daedeok-daero 989 beon-gil, Yuseong-gu, Daejeon 34057, Republic of Korea $\dagger$ Electronic supplementary information (ESI) available. See DOI: 10.1039/ D0DT01982H
}

chemical behaviour of plutonium in the environment because plutonium can simultaneously exist in multiple oxidation states $(+3,+4,+5$, and +6$)$ in a single aquatic system, and aquatic plutonium (bio)geochemistry is exclusively governed by the oxidation state. ${ }^{4}$ For instance, tetravalent plutonium, $\mathrm{Pu}$ (Iv), is considered insoluble and readily adsorbed, but Pu(Iv) transport can be facilitated by colloids. However, hexavalent plutonium, $\mathrm{Pu}(\mathrm{vI})$, is relatively soluble and behaves as an aqueous species due to its complexation with a variety of inorganic and organic ligands. ${ }^{5}$

Natural waters such as rainwater, groundwater, and seawater can not only leach plutonium from plutonium-bearing pollutants but also transport plutonium. The oxidation state and aqueous speciation of plutonium are of utmost importance for the understanding of plutonium transport and migration via natural fluids. In contact with atmospheric air, natural waters are oxidizing, and the higher oxidation states of plutonyl ions, namely, $\mathrm{Pu}(\mathrm{v})$ and $\mathrm{Pu}(\mathrm{vi})$, are widely observed in oxic rainwater, surface groundwater, seawater, and drinking water. $^{2,6-9}$ Radiolysis also plays an important role in the oxi- 
dation of plutonium and the stabilization of a high oxidation state. ${ }^{9,10}$ In the weakly acidic to weakly alkaline $\mathrm{pH}$ range $(\mathrm{pH}$ $5-9)$ of natural water, carbonate ion $\left(\mathrm{CO}_{3}{ }^{2-}\right)$ is one of the most influential ligands in aquatic chemistry due to its high concentration and strong affinity for cations. In oxidizing natural waters of neutral to weakly alkaline $\mathrm{pH}$, plutonyl(v,vI)carbonato species such as $\mathrm{PuO}_{2} \mathrm{CO}_{3}{ }^{-}$and $\mathrm{PuO}_{2}\left(\mathrm{CO}_{3}\right)_{2}{ }^{2-}$ are expected to be the dominant aqueous plutonium species ${ }^{5,11,12}$ based on a thermodynamic database ${ }^{13}$ and modelling.

Beyond the binary carbonato complexes, ternary complexes containing divalent alkaline earth ions were found for hexavalent uranium, $\mathrm{U}(\mathrm{vI}),{ }^{14}$ and are regarded as the major $\mathrm{U}(\mathrm{vI})$ complexes. Over the past two decades, the formation of ternary species $\left(\mathrm{M}_{x} \mathrm{UO}_{2}\left(\mathrm{CO}_{3}\right)_{3}{ }^{2 x-4}, \mathrm{M}=\mathrm{Ca}^{2+}\right.$ and $\left.\mathrm{Mg}^{2+}\right)$ has been intensively studied and the $\mathrm{M}_{x} \mathrm{UO}_{2}\left(\mathrm{CO}_{3}\right)_{3}{ }^{2 x-4}$ complexes are the dominant aqueous $\mathrm{U}(\mathrm{vI})$ species in the presence of naturally abundant $\mathrm{Ca}^{2+}$ and $\mathrm{Mg}^{2+}$ ions in groundwater and seawater. ${ }^{15-25}$ In addition to their overwhelming predominance in aqueous $\mathrm{U}(\mathrm{vI})$ species in natural waters, the ternary complexes are U(vI) species with significantly increased mobility resulting from decreased $\mathrm{U}(\mathrm{vI})$ sorption $^{26-28}$ and hindered reduction to immobile tetravalent uranium..$^{29-32}$ In a field study, the occurrence of $\mathrm{Ca}_{2} \mathrm{UO}_{2}\left(\mathrm{CO}_{3}\right)_{3}(\mathrm{aq})$ was observed even in deep, reducing, $\mathrm{Fe}(\mathrm{II})$-containing groundwater $\left(E_{\mathrm{h}}-140 \mathrm{mV}\right.$, $\sim 500$ metres below sea level). ${ }^{33}$ A study of uranium speciation in sea urchins identified the uptake of uranium in the form of ternary calcium carbonato species. ${ }^{34}$ Although ternary complexation is very striking with respect to the common fate of uranium under various environmental conditions, it has not been reported for hexavalent actinides other than $\mathrm{U}(\mathrm{vI})$.

Here, we identify the ternary complexation of plutonyl(vi) tricarbonate with calcium and magnesium ions for the first time. Visible-near infrared (vis-NIR) absorption spectroscopy is employed to elucidate the chemical interaction of $\mathrm{Ca}^{2+}$ and $\mathrm{Mg}^{2+}$ with plutonyl(vi) carbonate species. Among the various chemical models, a chemical model involving the formation of $\mathrm{CaPuO}_{2}\left(\mathrm{CO}_{3}\right)_{3}{ }^{2-}$ confirms our spectrophotometric results. Finally, the noticeable impacts of the ternary complexation of $\mathrm{Pu}(\mathrm{vI})$ on its aqueous chemistry and mobility in the environment are discussed based on the obtained formation constants for $\mathrm{CaPuO}_{2}\left(\mathrm{CO}_{3}\right)_{3}{ }^{2-}$ and $\mathrm{MgPuO}_{2}\left(\mathrm{CO}_{3}\right)_{3}{ }^{2-}$.

\section{Experimental section}

\subsection{Cautions}

Plutonium is radioactive and toxic. For experiments with plutonium, a restricted area with appropriate safety equipment and authorization is required. In this work, the plutonium solutions were carefully handled in a chemical fume hood and negative pressure glove box.

\subsection{Chemicals}

Plutonium stock solution was prepared by the dissolution of $\mathrm{PuO}_{2}$ (ORNL, ${ }^{242} \mathrm{Pu}$ : 99.932\% with trace levels of ${ }^{238} \mathrm{Pu},{ }^{239} \mathrm{Pu}$, ${ }^{240} \mathrm{Pu},{ }^{241} \mathrm{Pu}$, and ${ }^{244} \mathrm{Pu}$ ) with concentrated $\mathrm{HNO}_{3}$ and a small amount of HF. ${ }^{241} \mathrm{Am}$ generated from the $\beta$-decay of ${ }^{241} \mathrm{Pu}$ was separated from the plutonium stock solution by anion exchange (AG 1-X8, Bio-Rad). The background electrolyte $\left(\mathrm{HNO}_{3}\right.$ and $\left.\mathrm{HF}\right)$ was converted to $\mathrm{HClO}_{4}$ by fuming with concentrated $\mathrm{HClO}_{4}$ solution before drying and re-dissolution. The absence of the oxidation states of plutonium other than +6 was confirmed by vis-NIR absorption spectroscopy. Ultrafiltration (10 kDa, Ultracel YM regenerated cellulose membrane, Centricon-10, Millipore) was employed to eliminate particulates and the breakdown probability obtained using laserinduced breakdown detection (LIBD) of the $\mathrm{Pu}(\mathrm{vI})$ stock solution was comparable to that of ultrapure water (Milli-Q, Merck Millipore), which indicates the absence of particulates in the solution. The concentration of the $\mathrm{Pu}(\mathrm{vI})$ stock solution was determined to be $6 \mathrm{mM}$ by liquid scintillation counting (LSC). The detailed experimental setups for LIBD have been described elsewhere. ${ }^{35,36}$ Aliquots of plutonium stock solution were taken to obtain the desired plutonium concentration.

Stock solutions of $0.5 \mathrm{M} \mathrm{Na}_{2} \mathrm{CO}_{3}$ and $1.5 \mathrm{M} \mathrm{NaClO}_{4}$ were prepared by the dissolution of anhydrous $\mathrm{Na}_{2} \mathrm{CO}_{3}$ (99.999\%, Aldrich) and hydrate $\mathrm{NaClO}_{4}$ (99.99\%, Aldrich), respectively, in Milli-Q water. $\mathrm{Pu}(\mathrm{vI})$ samples for vis-NIR spectrophotometric titration were prepared with a $\mathrm{Pu}$ concentration of 0.35-0.40 mM. The initial carbonate concentration was set to $18 \mathrm{mM}$. To minimize the reduction of $\mathrm{Pu}, \mathrm{NaOCl}$ was spiked at a $0.2 \mathrm{mM}$ concentration of hypochlorite in the samples. $\mathrm{HClO}_{4}$ (99.999\%, Aldrich) was used to adjust the $\mathrm{pH}$ of the $\mathrm{Pu}$ samples. The $\mathrm{pH}$ was measured using a combination glass Ross-type electrode (Thermo Scientific Orion) filled with $3 \mathrm{M}$ $\mathrm{KCl}$ calibrated with $\mathrm{pH}$ buffers $(\mathrm{pH} 4.01,7.00$, and 10.01, Thermo Scientific Orion). The $\mathrm{pH}$ measurement was carried with a separated and duplicated sample solution in each titration step. The $\mathrm{pH}$ values mentioned throughout this manuscript are the measured values. The magnesium and calcium titrants were prepared by the dissolution of $\mathrm{Mg}\left(\mathrm{ClO}_{4}\right)_{2} \cdot 4 \mathrm{H}_{2} \mathrm{O}$ (99\%, Aldrich) and $\mathrm{Ca}\left(\mathrm{ClO}_{4}\right)_{2} \cdot 4 \mathrm{H}_{2} \mathrm{O}(99 \%$, Aldrich) in $0.1 \mathrm{M}$ $\mathrm{NaClO}_{4}$ to obtain $0.23 \mathrm{M} \mathrm{Mg}^{2+}$ and $0.14 \mathrm{M} \mathrm{Ca}^{2+}$. The ionic strength of the $\mathrm{Pu}(\mathrm{vI})$ sample was set to $0.1 \mathrm{M} \mathrm{H} / \mathrm{NaClO}_{4}$. All solutions were prepared with ultrapure Milli-Q water (18.2 $\left.\mathrm{M} \Omega \mathrm{cm}^{-1}\right)$. The plutonium concentration was measured using LSC (Tri-Carb 3110TR, PerkinElmer) and the concentrations of magnesium and calcium were analysed by inductively coupled plasma-optical emission spectroscopy (ICP-OES).

\subsection{Vis-NIR spectrophotometry and data processing}

A $2.5 \mathrm{~mL}$ Pu sample was contained in a sealable quartz cell (Hellma Analytics) with an optical path length of $1 \mathrm{~cm}$, and the cell was mounted in a temperature-controllable cuvette holder (Agilent Technologies) during the measurement. The vis-NIR absorption spectra were recorded by a spectrophotometer (Cary 5000, Agilent) at $25^{\circ} \mathrm{C}$. To increase the concentrations of $\mathrm{H}^{+}, \mathrm{Mg}^{2+}$, and $\mathrm{Ca}^{2+}$, aliquots of $\mathrm{HClO}_{4}$ and titrants, $\mathrm{Mg}\left(\mathrm{ClO}_{4}\right)_{2}$ and $\mathrm{Ca}\left(\mathrm{ClO}_{4}\right)_{2}$ in $0.1 \mathrm{M} \mathrm{NaClO}_{4}$, were added, and the sample was equilibrated for $10 \mathrm{~min}$ with magnetic stirring before the absorption measurements. The equilibrium constants and absorption spectra of each species were calcu- 
lated from the recorded spectra using a minimization program (Hypspec2014). ${ }^{37}$ For the fitting of the spectrophotometric results and the calculation of formation constants and absorption spectra of $\mathrm{CaPuO}_{2}\left(\mathrm{CO}_{3}\right)_{3}{ }^{2-}$, the aqueous species $\mathrm{H}_{2} \mathrm{CO}_{3}, \mathrm{HCO}_{3}{ }^{-}, \mathrm{NaHCO}_{3}, \mathrm{NaCO}_{3}{ }^{-}, \mathrm{CaHCO}_{3}{ }^{+}, \mathrm{CaCO}_{3}$, $\mathrm{PuO}_{2}\left(\mathrm{CO}_{3}\right)_{2}{ }^{2-}, \mathrm{PuO}_{2}\left(\mathrm{CO}_{3}\right)_{3}{ }^{4-}, \mathrm{H}^{+}$, and $\mathrm{OH}^{-}$were included in the model as the existing species in the system. The equilibrium constants were obtained from ref. 13 and 38 and corrected to those at $0.1 \mathrm{M} \mathrm{H} / \mathrm{NaClO}_{4}$ based on the specific ion interaction theory (SIT) ${ }^{39}$ and the corresponding coefficients in ref. 40 and 41 . The absorption spectrum in the range of $873 \mathrm{~nm}$ to $899 \mathrm{~nm}$ was excluded from data processing due to the meaningless signals with noisy fluctuation generated while exchanging the detectors of the spectrometer. All experiments were performed in triplicate. Errors of the data obtained in this work represent $\pm 1 \sigma$. The formation constant of $\mathrm{CaPuO}_{2}\left(\mathrm{CO}_{3}\right)_{3}{ }^{2-}$ was calculated to inherently include the errors of the formation constants of $\mathrm{PuO}_{2}\left(\mathrm{CO}_{3}\right)_{2}{ }^{2-}$ and $\mathrm{PuO}_{2}\left(\mathrm{CO}_{3}\right)_{3}{ }^{4-}$ since the $\log K$ values of $\mathrm{PuO}_{2}\left(\mathrm{CO}_{3}\right)_{2}{ }^{2-}$ and $\mathrm{PuO}_{2}\left(\mathrm{CO}_{3}\right)_{3}{ }^{4-}$ were taken into account in the calculation with their errors $( \pm 0.50)$. On the other hand, the error for the $\log K$ of $\mathrm{MgPuO}_{2}\left(\mathrm{CO}_{3}\right)_{3}{ }^{2-}$ was obtained independent of the errors for $\mathrm{PuO}_{2}\left(\mathrm{CO}_{3}\right)_{2}{ }^{2-}$ and $\mathrm{PuO}_{2}\left(\mathrm{CO}_{3}\right)_{3}{ }^{4-}$.

The stepwise formation constants of $\mathrm{MgPuO}_{2}\left(\mathrm{CO}_{3}\right)_{3}{ }^{2-}$ and

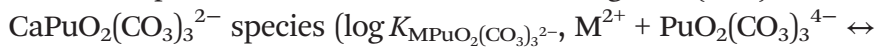
$\mathrm{MPuO}_{2}\left(\mathrm{CO}_{3}\right)^{2-}, \mathrm{M}=\mathrm{Mg}$ and $\left.\mathrm{Ca}\right)$ at infinite dilution were determined using the Davies equation. ${ }^{43}$

\subsection{Geochemical modelling}

PHREEQC (version 3$)^{44}$ was used to calculate the aqueous Pourbaix diagram $\left(E_{\mathrm{h}}-\mathrm{pH}\right.$ diagram) and $\mathrm{Pu}(\mathrm{vI})$ speciation with $\mathrm{pH}$ at $25^{\circ} \mathrm{C}$ and infinite dilution. The thermodynamic data for $\mathrm{Pu}(\mathrm{vI})$ species were basically obtained from NEA-TDB in PHREEQC format (updated in November, 2018). ${ }^{45}$ For the formation constants of $\mathrm{MgPuO}_{2}\left(\mathrm{CO}_{3}\right)_{3}{ }^{2-}$ and $\mathrm{CaPuO}_{2}\left(\mathrm{CO}_{3}\right)_{3}{ }^{2-}$, the data obtained in this work were used. For the aqueous and solid species for calcium, magnesium, and carbonate, the thermodynamic data of WATEQ4F ${ }^{38}$ were used. In the calcu- lations, calcite, magnesite, dolomite, $\mathrm{PuO}_{2} \mathrm{CO}_{3}(\mathrm{cr})$, and $\mathrm{PuO}_{2}(\mathrm{OH})_{2} \cdot \mathrm{H}_{2} \mathrm{O}(\mathrm{cr})$ were taken into account as solubility limiting phases. The Pourbaix diagram was illustrated using PhreePlot software. ${ }^{46}$

\section{Results and discussion}

\subsection{Vis-NIR absorption spectral properties of $\mathrm{PuO}_{2}\left(\mathrm{CO}_{3}\right)_{2}{ }^{2-}$ and $\mathrm{PuO}_{2}\left(\mathrm{CO}_{3}\right)_{3}{ }^{4-}$}

Prior to the investigation of $\mathrm{Ca}^{2+}$ complexation with plutonyl(vi) carbonate species, the vis-NIR absorption characteristics of $\mathrm{PuO}_{2}\left(\mathrm{CO}_{3}\right)_{2}{ }^{2-}$ and $\mathrm{PuO}_{2}\left(\mathrm{CO}_{3}\right)_{3}{ }^{4-}$ species were identified. Fig. 1a and $b$ show the results of a vis-NIR spectrophotometric titration with decreasing $\mathrm{pH}$. At the starting point of the spectrophotometric titration ( $\mathrm{pH} 9.78$, Fig. 1a and b), the aqueous $\mathrm{Pu}(\mathrm{vI})$ speciation is calculated to be $100 \% \mathrm{PuO}_{2}\left(\mathrm{CO}_{3}\right)_{3}{ }^{4-}$ by thermodynamic modelling based on the critically reviewed NEA-TDB (ESI, Fig. S1 $\dagger$ ), and the recorded spectrum at pH 9.78 is identical to the absorption spectrum of $\mathrm{Pu}(\mathrm{vI})$ observed under concentrated carbonate conditions at a strongly alkaline $\mathrm{pH}(2 \mathrm{M}$ $\mathrm{Na}_{2} \mathrm{CO}_{3}, \mathrm{pH}$ 12.6) in a previous study. ${ }^{47}$ It is therefore assumed that the spectrophotometric titration starts at $100 \%$ $\mathrm{PuO}_{2}\left(\mathrm{CO}_{3}\right)_{3}{ }^{4-}$, and the observed spectrum of $\mathrm{Pu}(\mathrm{vI})$ at the initial point ( $\mathrm{pH}$ 9.78) is ascribed to the characteristic absorption spectrum of $\mathrm{PuO}_{2}\left(\mathrm{CO}_{3}\right)_{3}{ }^{4-}$. The characteristic sharp absorption peak of $\mathrm{PuO}_{2}{ }^{2+}$ ions at $830 \mathrm{~nm}$ completely disappears due to carbonato complexation, and instead, broad absorption from $500 \mathrm{~nm}$ to $650 \mathrm{~nm}$ (molar absorptivity $\varepsilon=55.7 \pm 2.8 \mathrm{M}^{-1} \mathrm{~cm}^{-1}$ at the peak position of $569 \mathrm{~nm}$ ) is observed. In addition, the observed absorption bands in the ranges of $840-870 \mathrm{~nm}, 900-960 \mathrm{~nm}$, and 1000-1120 $\mathrm{nm}$ are comparable to the reported absorption bands of $\mathrm{Pu}(\mathrm{vI})$ carbonate species in previous work. ${ }^{47,48}$

As the $\mathrm{pH}$ decreased, the recorded absorption spectra gradually changed (Fig. 1a and b), indicating chemical changes in the aqueous $\mathrm{Pu}(\mathrm{VI})$ species. A decrease in absorbance with a continuous hypsochromic shift in the broad absorption between $500 \mathrm{~nm}$ and $650 \mathrm{~nm}$ and the appearance
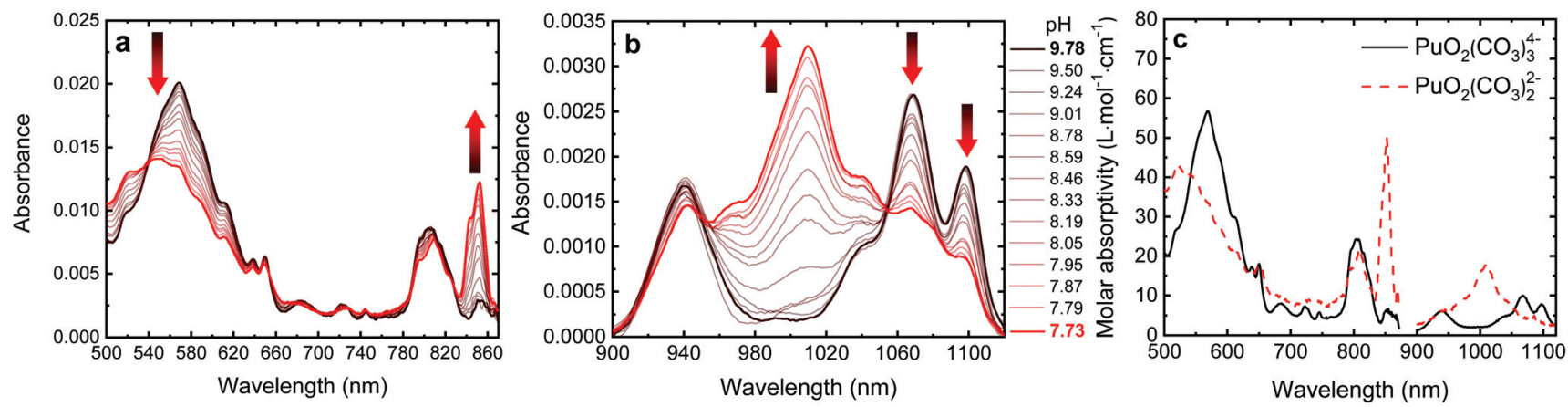

Fig. 1 Representative results of the spectrophotometric $\mathrm{pH}$ titration of the plutonyl( $\mathrm{vl})$ carbonate system $\left([\mathrm{Pu}(\mathrm{Vv})]=0.36 \mathrm{mM}\left[\mathrm{CO}_{3}{ }^{2-}\right]_{\text {total }}=18 \mathrm{mM}^{1}\right.$ $\mathrm{pH} 9.78$ (black line) to 7.73 (red line), and $I=0.1 \mathrm{M} \mathrm{H} / \mathrm{NaClO}_{4}$ ) with decreasing $\mathrm{pH}$ in the wavelength ranges of (a) $500-870 \mathrm{~nm}$ and (b) 900-1120 nm. The arrows indicate a gradual increase (up) and decrease (down) in absorbance due to acidification. (c) Vis-NIR absorption spectra (500-1120 nm) of $\mathrm{PuO}_{2}\left(\mathrm{CO}_{3}\right)_{3}{ }^{4-}$ (solid line, measured at $\mathrm{pH}$ 9.78) and $\mathrm{PuO}_{2}\left(\mathrm{CO}_{3}\right)_{2}{ }^{2-}$ (dotted line, determined from the equilibrium constant of the transition reaction, $\left.\mathrm{PuO}_{2}\left(\mathrm{CO}_{3}\right)_{3}{ }^{4-} \leftrightarrow \mathrm{PuO}_{2}\left(\mathrm{CO}_{3}\right)_{2}{ }^{2-}+\mathrm{CO}_{3}{ }^{2-}\right)$. 
of isosbestic points at 540, 654, 823, 953, and $1054 \mathrm{~nm}$ representing a one-to-one transition of $\mathrm{PuO}_{2}\left(\mathrm{CO}_{3}\right)_{3}{ }^{4-}$ to $\mathrm{PuO}_{2}\left(\mathrm{CO}_{3}\right)_{2}{ }^{2-}$ are observed with decreasing $\mathrm{pH}$. With acidification, absorption bands at $853 \mathrm{~nm}$ and $1010 \mathrm{~nm}$ appear and gradually grow, whereas the intensity of the double peaks in the 1000-1120 $\mathrm{nm}$ region decreases.

In addition to the characteristic changes in the absorption spectra, the calculated equilibrium constant also supports a change in aqueous $\mathrm{Pu}(\mathrm{vI})$ species from $\mathrm{PuO}_{2}\left(\mathrm{CO}_{3}\right)_{3}{ }^{4-}$ to $\mathrm{PuO}_{2}\left(\mathrm{CO}_{3}\right)_{2}{ }^{2-}$ after comparison with the reported thermodynamic data. The chemical reaction is as follows:

$$
\mathrm{PuO}_{2}\left(\mathrm{CO}_{3}\right)_{3}{ }^{4-} \leftrightarrow \mathrm{PuO}_{2}\left(\mathrm{CO}_{3}\right)_{2}{ }^{2-}+\mathrm{CO}_{3}{ }^{2-}
$$

From the results of the spectrophotometric titration, the equilibrium constant $(\log K)$ of reaction (1) is calculated to be $-4.02 \pm 0.19$ at $0.1 \mathrm{M} \mathrm{H} / \mathrm{NaClO}_{4}$ by the data processing software $^{37}$ and is corrected to $-3.15 \pm 0.20$ at infinite dilution by SIT $^{39}$ using ion interaction coefficients from previous work. ${ }^{41}$ The corrected formation constant of $-3.15 \pm 0.20$ is very comparable to the value of $-3.30 \pm 1.02$, which resulted from the difference in the Gibb's free energies of formation for $\mathrm{PuO}_{2}\left(\mathrm{CO}_{3}\right)_{2}{ }^{2-}$ and $\mathrm{PuO}_{2}\left(\mathrm{CO}_{3}\right)_{3}{ }^{4-}$ species. ${ }^{13}$ These critically reviewed formation constants of reactions (2) and (3) are $14.7 \pm$ 0.50 and $18.0 \pm 0.50$, respectively.

$$
\begin{aligned}
& \mathrm{PuO}_{2}{ }^{2+}+2 \mathrm{CO}_{3}{ }^{2-} \leftrightarrow \mathrm{PuO}_{2}\left(\mathrm{CO}_{3}\right)_{2}{ }^{2-} \\
& \mathrm{PuO}_{2}{ }^{2+}+3 \mathrm{CO}_{3}{ }^{2-} \leftrightarrow \mathrm{PuO}_{2}\left(\mathrm{CO}_{3}\right)_{3}{ }^{4-}
\end{aligned}
$$

The stability constants and interaction coefficients of $\mathrm{Pu}(\mathrm{vI})$ carbonate species in $0.202 \mathrm{~m} \mathrm{NaClO}_{4}$ were recently revisited by coupling capillary electrophoresis and ICP-MS. ${ }^{41}$ The newly obtained stability constants at infinite dilution based on the reactions (2) and (3) were $14.99 \pm 0.06$ and $17.94 \pm 0.30$, respectively. This corresponds to $-2.95 \pm 0.31$ for reaction (1), which is also comparable to our data $(-3.15 \pm 0.20)$.

The aqueous $\mathrm{Pu}(\mathrm{vI})$ speciation from the spectrophotometry in this study and from the thermodynamic modelling with NEA-TDB are in good agreement (ESI, Fig. S1†). Along with the equilibrium constant of reaction (1), the pure absorption spectrum of $\mathrm{PuO}_{2}\left(\mathrm{CO}_{3}\right)_{2}{ }^{2-}$ is obtained accordingly based on the results of the potentiometric titration (Fig. 1c). The molar absorptivity of the most prominent peak of $\mathrm{PuO}_{2}\left(\mathrm{CO}_{3}\right)_{2}{ }^{2-}$ at $853 \mathrm{~nm}$ is determined to be $49.0 \pm 4.2 \mathrm{M}^{-1} \mathrm{~cm}^{-1}$. Notably, a shoulder peak in the vicinity of the $\mathrm{PuO}_{2}\left(\mathrm{CO}_{3}\right)_{2}{ }^{2-}$ band at $853 \mathrm{~nm}$ arises at approximately $843 \mathrm{~nm}$ below $\mathrm{pH}$ 8.2. Thermodynamic modelling reveals the formation of plutonyl(vi) monocarbonate species in very low abundance, $<5 \%$. To avoid interference from $\mathrm{Pu}(\mathrm{vI})$ species other than $\mathrm{PuO}_{2}\left(\mathrm{CO}_{3}\right)_{2}{ }^{2-}$ and $\mathrm{PuO}_{2}\left(\mathrm{CO}_{3}\right)_{3}{ }^{4-}$, the equilibrium constant and the absorption spectrum of $\mathrm{PuO}_{2}\left(\mathrm{CO}_{3}\right)_{2}{ }^{2-}$ species are determined using the result obtained above pH 8.2.

\subsection{Interaction of $\mathrm{Ca}^{2+}$ with $\mathrm{Pu}(\mathrm{vI})$ carbonate species}

On the basis of the absorption spectral information of $\mathrm{PuO}_{2}\left(\mathrm{CO}_{3}\right)_{2}{ }^{2-}$ and $\mathrm{PuO}_{2}\left(\mathrm{CO}_{3}\right)_{3}{ }^{4-}$, the ternary complexation of plutonyl(vi)carbonate species with $\mathrm{Ca}^{2+}$ is investigated (Fig. 2). At $808 \mathrm{~nm}$, a new sharp peak, which is not observed in the $\mathrm{PuO}_{2}\left(\mathrm{CO}_{3}\right)_{2}{ }^{2-} / \mathrm{PuO}_{2}\left(\mathrm{CO}_{3}\right)_{3}{ }^{4-}$ system, appears after adding $\mathrm{Ca}^{2+}$ and is thus a strong indication of the interaction of $\mathrm{Ca}^{2+}$ with $\mathrm{Pu}(\mathrm{vI})$ carbonate species. Together with the growth of this peak at $808 \mathrm{~nm}$ characteristic of the interaction with $\mathrm{Ca}^{2+}$, the broad absorption band between $500 \mathrm{~nm}$ and $650 \mathrm{~nm}$, representing the equilibrium of $\mathrm{PuO}_{2}\left(\mathrm{CO}_{3}\right)_{2}{ }^{2-}$ and $\mathrm{PuO}_{2}\left(\mathrm{CO}_{3}\right)_{3}{ }^{4-}$, undergoes a bathochromic shift after addition of $\mathrm{Ca}^{2+}$ even at a constant pH of 7.9 during the titration. These spectral features are identical to other spectrophotometric $\mathrm{Ca}^{2+}$ titrations with varying starting $\mathrm{pH}$ values and different ratios of $\mathrm{PuO}_{2}\left(\mathrm{CO}_{3}\right)_{2}{ }^{2-}$ / $\mathrm{PuO}_{2}\left(\mathrm{CO}_{3}\right)_{3}{ }^{4-}$ (ESI, Fig. S2 $\dagger$ ). This unambiguously indicates that a simultaneous interaction of $\mathrm{Ca}^{2+}$ with $\mathrm{PuO}_{2}\left(\mathrm{CO}_{3}\right)_{2}{ }^{2-}$ and $\mathrm{PuO}_{2}\left(\mathrm{CO}_{3}\right)_{3}{ }^{4-}$ is unlikely. In addition, the clear isosbestic points at 540 and $651 \mathrm{~nm}$ are independent of the $\mathrm{pH}$ of the $\mathrm{Ca}^{2+}$ titration, indicating that only one $\mathrm{Ca}-\mathrm{Pu}(\mathrm{vI})$ carbonate species is formed: either $\mathrm{Ca}^{2+}-\mathrm{PuO}_{2}\left(\mathrm{CO}_{3}\right)_{2}{ }^{2-}$ or $\mathrm{Ca}^{2+}$ $\mathrm{PuO}_{2}\left(\mathrm{CO}_{3}\right)_{3}{ }^{4-}$. The redshift in the broad peak (500-650 nm) and the disappearance of absorbance at $853 \mathrm{~nm}$ correspond to the change in the aqueous $\mathrm{Pu}(\mathrm{vI})$ species from $\mathrm{PuO}_{2}\left(\mathrm{CO}_{3}\right)_{2}{ }^{2-}$ to $\mathrm{PuO}_{2}\left(\mathrm{CO}_{3}\right)_{3}{ }^{4-}$. The absorption spectrum of the newly formed $\mathrm{Ca}^{2+}-\mathrm{Pu}(\mathrm{vI})$ carbonate species is similar to that of $\mathrm{PuO}_{2}\left(\mathrm{CO}_{3}\right)_{3}{ }^{4-}$, except for a distinguishable absorption band at $808 \mathrm{~nm}$. In addition, the characteristic peak of $\mathrm{PuO}_{2}\left(\mathrm{CO}_{3}\right)_{2}{ }^{2-}$ at $853 \mathrm{~nm}$ is attenuated by the addition of $\mathrm{Ca}^{2+}$ and nearly vanishes at the end of the $\mathrm{Ca}^{2+}$ titration $\left(\left[\mathrm{Ca}^{2+}\right]=0.72 \mathrm{mM}\right)$, which reflects a significant decrease in the $\mathrm{PuO}_{2}\left(\mathrm{CO}_{3}\right)_{2}{ }^{2-}$ concentration with $\mathrm{Ca}^{2+}$ addition. Thus, $\mathrm{Ca}^{2+}$ likely interacts with $\mathrm{PuO}_{2}\left(\mathrm{CO}_{3}\right)_{3}{ }^{4-}$ rather than $\mathrm{PuO}_{2}\left(\mathrm{CO}_{3}\right)_{2}{ }^{2-}$. This interaction is also experimentally confirmed by the results of the spectrophotometric titration at $\mathrm{pH}$ 9.1, showing the appearance of the peak at $808 \mathrm{~nm}$ even in the absence of $\mathrm{PuO}_{2}\left(\mathrm{CO}_{3}\right)_{2}{ }^{2-}$ (Fig. 2b).

Slope analysis (Fig. 2c) was conducted to determine the stoichiometric number $(x)$ of $\mathrm{Ca}^{2+}$ complexing with $\mathrm{PuO}_{2}\left(\mathrm{CO}_{3}\right)_{3}{ }^{4-}$. The chemical reaction of $\mathrm{Ca}^{2+}$ with $\mathrm{PuO}_{2}\left(\mathrm{CO}_{3}\right)_{3}{ }^{4-}$ and its equilibrium constant of $\mathrm{Ca}_{x} \mathrm{PuO}_{2}\left(\mathrm{CO}_{3}\right)_{3}{ }^{2 x-4}(\log K)$ are described with the concentration ratio $(R)$ of $\mathrm{Ca}^{2+}$-complexed and uncomplexed plutonyl(vi) species, i.e., $\left[\mathrm{Ca}_{x} \mathrm{PuO}_{2}\left(\mathrm{CO}_{3}\right)_{3}{ }^{2 x-4}\right] /$ $\left[\mathrm{PuO}_{2}\left(\mathrm{CO}_{3}\right)_{3}{ }^{4-}\right]$, as follows:

$$
\begin{gathered}
x \mathrm{Ca}^{2+}+\mathrm{PuO}_{2}\left(\mathrm{CO}_{3}\right)_{3}{ }^{4-} \leftrightarrow \mathrm{Ca}_{x} \mathrm{PuO}_{2}\left(\mathrm{CO}_{3}\right)_{3}{ }^{2 x-4} \\
\log K=\log R-x \cdot \log \left[\mathrm{Ca}^{2+}\right]
\end{gathered}
$$

At the first measurement point, the total $\mathrm{Pu}(\mathrm{vI})$ concentration $\left([\mathrm{Pu}]_{\text {total }}\right)$ is the sum of the concentrations of $\mathrm{PuO}_{2}\left(\mathrm{CO}_{3}\right)_{2}{ }^{2-}$ and $\mathrm{PuO}_{2}\left(\mathrm{CO}_{3}\right)_{3}{ }^{4-}$ in the absence of $\mathrm{Ca}^{2+}$. In each step of the titration, the concentration of $\mathrm{PuO}_{2}\left(\mathrm{CO}_{3}\right)_{2}{ }^{2-}$ is determined from the absorbance $\left(A_{853}\right)$ and the molar absorptivity at $853 \mathrm{~nm}\left(\varepsilon_{853}, \mathrm{PuO}_{2}\left(\mathrm{CO}_{3}\right)_{2}{ }^{2-}\right)$, where the characteristic peak of $\mathrm{PuO}_{2}\left(\mathrm{CO}_{3}\right)_{2}{ }^{2-}$ is located. The concentration ratio of $\mathrm{PuO}_{2}\left(\mathrm{CO}_{3}\right)_{3}{ }^{4-}$ to $\mathrm{PuO}_{2}\left(\mathrm{CO}_{3}\right)_{2}{ }^{2-}$ can be assumed to be constant $(C)$ in all steps of the $\mathrm{Ca}^{2+}$ titration at a consistent $\mathrm{pH}$ and $\mathrm{CO}_{3}{ }^{2-}$ concentration; thus, the concentration of $\mathrm{Ca}_{x} \mathrm{PuO}_{2}\left(\mathrm{CO}_{3}\right)_{3}{ }^{2 x-4}$ is calculated from the $\mathrm{Pu}(\mathrm{vI})$ concentration balance. Accordingly, the concentration ratio $(R)$ of $\mathrm{Ca}^{2+}$ - 

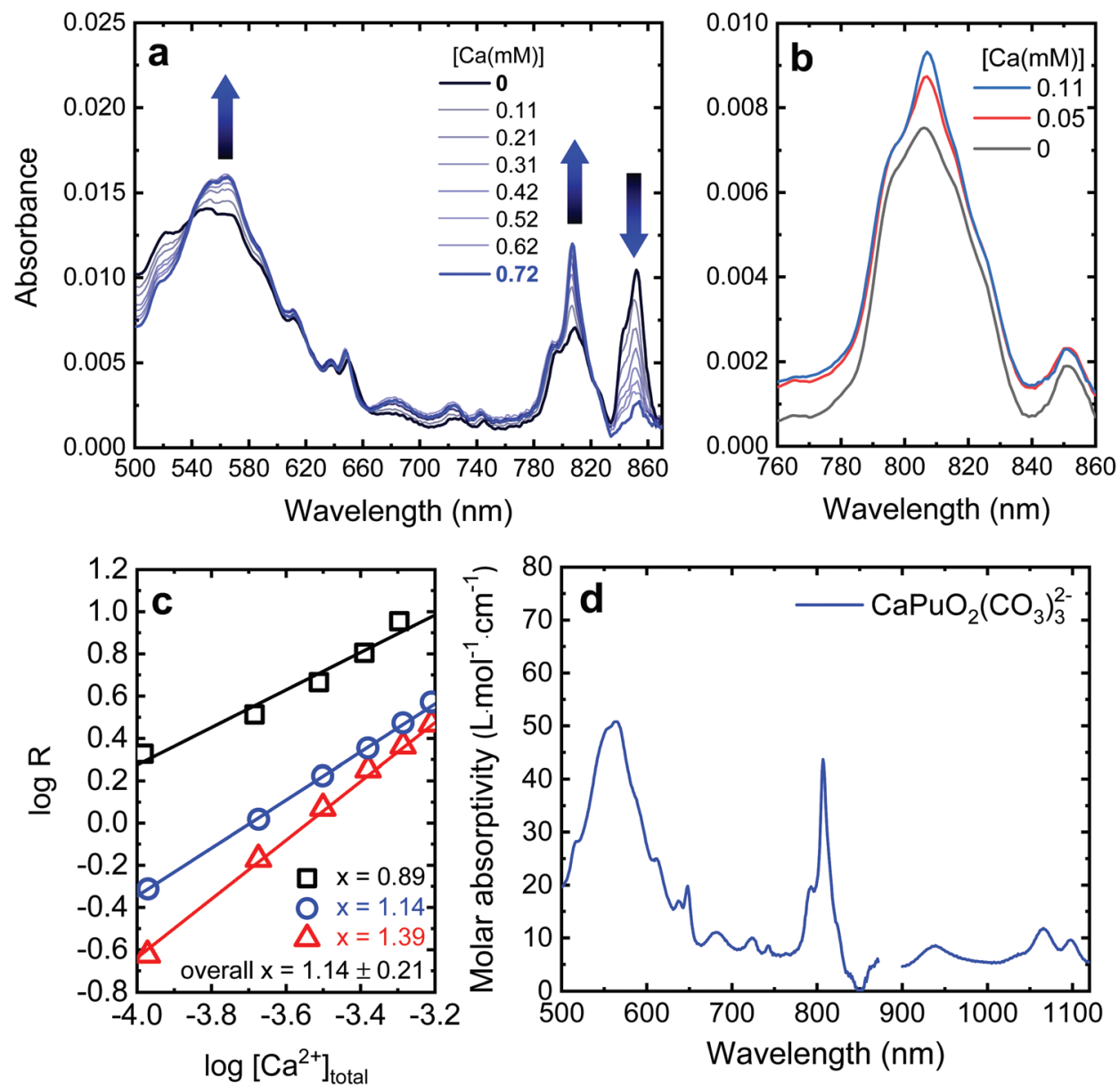

Fig. 2 Results of the spectrophotometric $\mathrm{Ca}^{2+}$ titration. (a) Representative results of the spectrophotometric $\mathrm{Ca}^{2+}$ titration of the plutonyl(vi)carbonate system $\left([\mathrm{Pu}(\mathrm{vl})]=0.39 \mathrm{mM},\left[\mathrm{CO}_{3}{ }^{2-}\right]_{\text {total }}=17 \mathrm{mM},\left[\mathrm{Ca}^{2+}\right]=0\right.$ to $0.72 \mathrm{mM}, \mathrm{pH} 7.9$, and $\left.I=0.1 \mathrm{M} \mathrm{H} / \mathrm{NaClO}_{4}\right)$ with increasing Ca ${ }^{2+}$ in the wavelength range of 500-870 $\mathrm{nm}$. The arrows indicate a gradual increase (up) and decrease (down) in absorbance due to Ca ${ }^{2+}$ complexation. (b) Increase in the peak at $808 \mathrm{~nm}$ under $\mathrm{PuO}_{2}\left(\mathrm{CO}_{3}\right)_{3}{ }^{4-}$-dominant conditions $\left([\mathrm{Pu}(\mathrm{vl})]=0.39 \mathrm{mM},\left[\mathrm{CO}_{3}{ }^{2-}\right]_{\text {total }}=17 \mathrm{mM},\left[\mathrm{Ca}{ }^{2+}\right]=0\right.$ to $0.11 \mathrm{mM}, \mathrm{pH} 9.1$, and $\left.I=0.1 \mathrm{M} \mathrm{H}^{2} \mathrm{NaClO}_{4}\right)$. (c) Results of a triplicate slope analysis $\left(\log R v s . \log \left[\mathrm{Ca}^{2+}\right]_{\text {total }}\right)$ with the slope $(x)$ representing the stoichiometric number of complexed $\mathrm{Ca}^{2+}$ obtained from linear regression. (d) Deconvoluted vis-NIR absorption spectra of $\mathrm{CaPuO}_{2}\left(\mathrm{CO}_{3}\right)_{3}{ }^{2-}$ from the results of the spectrophotometric $\mathrm{Ca}^{2+}$ titrations.

complexed and uncomplexed $\mathrm{Pu}$ species is rearranged in terms of the absorption properties as follows:

$$
\begin{aligned}
& {[\mathrm{Pu}]_{\text {total }}=\left[\mathrm{PuO}_{2}\left(\mathrm{CO}_{3}\right)_{2}{ }^{2-}\right]} \\
& +\left[\mathrm{PuO}_{2}\left(\mathrm{CO}_{3}\right)_{3}{ }^{4-}\right]+\left[\mathrm{Ca}_{x} \mathrm{PuO}_{2}\left(\mathrm{CO}_{3}\right)_{3}{ }^{2 x-4}\right] \\
& =\frac{A_{853}}{\varepsilon_{853, \mathrm{PuO}_{2}\left(\mathrm{CO}_{3}\right)_{2}{ }^{2-}}}+C \cdot \frac{A_{853}}{\varepsilon_{853, \mathrm{PuO}_{2}\left(\mathrm{CO}_{3}\right)_{2}{ }^{2-}}} \\
& +\left[\mathrm{Ca}_{x} \mathrm{PuO}_{2}\left(\mathrm{CO}_{3}\right)_{3}{ }^{2 x-4}\right] \\
& R=\frac{\left[\mathrm{Ca}_{x} \mathrm{PuO}_{2}\left(\mathrm{CO}_{3}\right)_{3}{ }^{2 x-4}\right]}{\left[\mathrm{PuO}_{2}\left(\mathrm{CO}_{3}\right)_{3}{ }^{4-}\right]} \\
& =\frac{\left([\mathrm{Pu}]_{\text {total }}-\frac{A_{853}}{\varepsilon_{853, \mathrm{PuO}_{2}\left(\mathrm{CO}_{3}\right)_{2}{ }^{2-}}}-C \cdot \frac{A_{853}}{\varepsilon_{853, \mathrm{PuO}_{2}\left(\mathrm{CO}_{3}\right)_{2}{ }^{2-}}}\right)}{C \cdot \frac{A_{853}}{\varepsilon_{853, \mathrm{PuO}_{2}\left(\mathrm{CO}_{3}\right)_{2}{ }^{2-}}}}
\end{aligned}
$$

As shown in Fig. 2c, the slope of $\log R$ vs. $\log \left[\mathrm{Ca}^{2+}\right]_{\text {total }}$ is $1.14 \pm 0.21$, indicating that the stoichiometric number of $\mathrm{Ca}^{2+}$ ions complexing with $\mathrm{PuO}_{2}\left(\mathrm{CO}_{3}\right)_{3}{ }^{4-}$ is close to 1 and $\mathrm{CaPuO}_{2}\left(\mathrm{CO}_{3}\right)_{3}{ }^{2-}$ species are formed. The positive deviation of the obtained slope from the ideal value of 1 may be attributed to an overestimation of the free $\mathrm{Ca}^{2+}$ ion concentration because the amount of $\mathrm{Ca}^{2+}$ actually consumed by complexation is neglected. Taking into account the consumed $\mathrm{Ca}^{2+}$ concentration based on the assumption of $x=1$, the slope is determined to be $0.94 \pm 0.26$ (ESI, Fig. S3†).

The formation of the monocalcium plutonyl(vi)tricarbonate, $\mathrm{CaPuO}_{2}\left(\mathrm{CO}_{3}\right)_{3}{ }^{2-}$, was also confirmed by the examination of possible chemical models. A chemical model based on the formation of $\mathrm{CaPuO}_{2}\left(\mathrm{CO}_{3}\right)_{3}{ }^{2-}$ shows a very successful fitting result with the spectrophotometric titration, and the stepwise

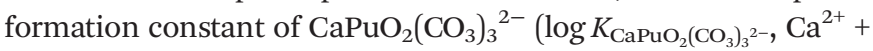
$\left.\mathrm{PuO}_{2}\left(\mathrm{CO}_{3}\right)_{3}{ }^{4-} \leftrightarrow \mathrm{CaPuO}_{2}\left(\mathrm{CO}_{3}\right)_{3}{ }^{2-}\right)$ corresponding to reaction (4) with $x=1$ is calculated to be $4.33 \pm 0.50$ in $0.1 \mathrm{M} \mathrm{H} / \mathrm{NaClO}_{4}$. The absorption spectrum of $\mathrm{CaPuO}_{2}\left(\mathrm{CO}_{3}\right)_{3}{ }^{2-}$ calculated from the results of spectrophotometric titration is presented in 
Fig. 2d. The stepwise formation constant of the similar uranyl (vi) species, $\mathrm{CaUO}_{2}\left(\mathrm{CO}_{3}\right)_{3}{ }^{2-}$, in $0.1 \mathrm{M} \mathrm{H} / \mathrm{NaClO}_{4}$ medium

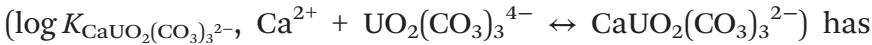
been reported to be $3.13 \pm 0.22^{20}$ and $3.00 \pm 0.25^{23}$ in previous work. Other chemical models presuming the formation of neutral $\mathrm{Ca}_{2} \mathrm{PuO}_{2}\left(\mathrm{CO}_{3}\right)_{3}(\mathrm{aq})$ species show unsatisfactory spectrophotometric results with failures in the spectral fitting procedure (ESI, Fig. S4 $\dagger$ ) and implausible formation constants. Even though the ternary $\mathrm{Ca}^{2+}$ complexation of $\mathrm{PuO}_{2}\left(\mathrm{CO}_{3}\right)_{3}{ }^{4-}$ is more favourable than that of $\mathrm{UO}_{2}\left(\mathrm{CO}_{3}\right)_{3}{ }^{4-}$, the di-calcium species, which is frequently observed for $\mathrm{U}(\mathrm{vI})$ as $\mathrm{Ca}_{2} \mathrm{UO}_{2}\left(\mathrm{CO}_{3}\right)_{3}(\mathrm{aq})$, appears to be difficult to form for $\mathrm{PuO}_{2}\left(\mathrm{CO}_{3}\right)_{3}{ }^{4-}$. $\mathrm{UO}_{2}\left(\mathrm{CO}_{3}\right)_{3}{ }^{4-}$ can be dominant even at a low $\mathrm{pH}$ and carbonate concentration, where a millimolar concentration of $\mathrm{Ca}^{2+}$ is sufficient to form di-calcium species that can be dissolved. However, in the case of $\mathrm{Pu}(\mathrm{vI})$, the formation of a considerable amount of $\mathrm{PuO}_{2}\left(\mathrm{CO}_{3}\right)_{3}{ }^{4-}$ requires a relatively high $\mathrm{pH}$ and carbonate concentration, but the amount of $\mathrm{Ca}^{2+}$ ions needed to form di-calcium species is limited due to the solubility limit imposed by the formation of $\mathrm{CaCO}_{3}(\mathrm{~s})$ under these conditions.

\section{3. $\mathrm{Mg}^{2+}-\mathrm{PuO}_{2}\left(\mathrm{CO}_{3}\right)_{3}{ }^{4-}$ system}

Similar to $\mathrm{Ca}^{2+}$ complexation, an identical trend in spectrophotometric changes is also observed for the titration with $\mathrm{Mg}^{2+}$ ions (ESI, Fig. S5 $\dagger$ ). However, the evolution of the absorbance is more insensitive to the $\mathrm{Mg}^{2+}$ concentration than to the $\mathrm{Ca}^{2+}$ system, which represents a stronger affinity of $\mathrm{Ca}^{2+}$ than that of $\mathrm{Mg}^{2+}$ for $\mathrm{PuO}_{2}\left(\mathrm{CO}_{3}\right)_{3}{ }^{4-}$. Because of this small spectral change in absorbance, even with a large variation in the $\mathrm{Mg}^{2+}$ concentrations compared to the $\mathrm{Ca}^{2+}$ system, data processing by the minimization software ${ }^{37}$ and the convolution of the characteristic absorption spectrum of $\mathrm{MgPuO}_{2}\left(\mathrm{CO}_{3}\right)_{3}{ }^{2-}$ are problematic. Instead, the concentration balance used in the slope analysis (eqn (4) and (5)) is utilized to quantitatively determine the concentration of $\mathrm{Mg}^{2+}$-complexed $\mathrm{PuO}_{2}\left(\mathrm{CO}_{3}\right)_{3}{ }^{4-}$ in each step of the titration based on the assumed formation of $\mathrm{MgPuO}_{2}\left(\mathrm{CO}_{3}\right)_{3}{ }^{2-}$. The stepwise formation constant of $\mathrm{MgPuO}_{2}\left(\mathrm{CO}_{3}\right)_{3}{ }^{2-}$ at $0.1 \mathrm{M} \quad \mathrm{H} / \mathrm{NaClO}_{4} \quad\left(\log K_{\left.\mathrm{MgPuO}_{2}\left(\mathrm{CO}_{3}\right)_{3}{ }^{2-}\right)}\right.$ is calculated to be $2.58 \pm 0.18$, which is smaller than

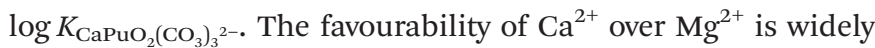
observed in $\mathrm{Mg}^{2+} / \mathrm{Ca}^{2+}-\mathrm{UO}_{2}\left(\mathrm{CO}_{3}\right)_{3}{ }^{4-}$ complexations as well. ${ }^{18,22,24}$

To make the formation constants applicable to thermodynamic modelling, the Davies equation ${ }^{43}$ is applied to correct the ionic strength to infinite dilution. The stepwise formations of $\mathrm{MgPuO}_{2}\left(\mathrm{CO}_{3}\right)_{3}{ }^{2-}$ and $\mathrm{CaPuO}_{2}\left(\mathrm{CO}_{3}\right)_{3}{ }^{2-}$ at infinite dilution are determined to be $\log \mathrm{K}^{\circ} \mathrm{MgPuO}_{2}\left(\mathrm{CO}_{3}\right)_{3}{ }^{2-}=$ $4.29 \pm 0.18$ and $\log K^{\circ} \mathrm{CaPuO}_{2}\left(\mathrm{CO}_{3}\right)_{3}{ }^{2-}=6.05 \pm 0.50$. To the best of our knowledge, the formations of $\mathrm{MgPuO}_{2}\left(\mathrm{CO}_{3}\right)_{3}{ }^{2-}$ and $\mathrm{CaPuO}_{2}\left(\mathrm{CO}_{3}\right)_{3}{ }^{2-}$ are reported for the first time in this work. For that reason, the ion interaction coefficients of the ternary plutonyl(vi) species are still unknown. Nonetheless, it is worth noting that the use of the SIT approach ${ }^{39}$ with the ion interaction coefficient of $\mathrm{CaUO}_{2}\left(\mathrm{CO}_{3}\right)_{3}{ }^{2-}$ with $\mathrm{Na}^{+}$ suggested from PSI/Nagra-TDB, ${ }^{42} \varepsilon\left(\mathrm{CaUO}_{2}\left(\mathrm{CO}_{3}\right)_{3}{ }^{2-}, \mathrm{Na}^{+}\right)=-$ $(0.1 \pm 0.1) \mathrm{kg} \cdot \mathrm{mol}^{-1}$, as a surrogate coefficient for $\mathrm{MPuO}_{2}\left(\mathrm{CO}_{3}\right)_{3}{ }^{2-}$ shows insignificant differences in $\log K^{\circ}$ $\left(4.27 \pm 0.19\right.$ and $6.02 \pm 0.50$ for $\mathrm{M}=\mathrm{Mg}^{2+}$ and $\mathrm{Ca}^{2+}$, respectively) with the values obtained using the Davies equation. ${ }^{43}$ Table 1 summarizes the formation constants of ternary plutonyl(vi) complexes in $0.1 \mathrm{M} \mathrm{H} / \mathrm{NaClO}_{4}$ and at infinite dilution (Davies equation ${ }^{43}$ ).

\subsection{Aqueous Pu speciation}

Fig. 3 presents the Pourbaix diagram (Eh-pH diagram) and the aqueous $\mathrm{Pu}(\mathrm{vI})$ species distribution based on the obtained thermodynamic data of $\mathrm{CaPuO}_{2}\left(\mathrm{CO}_{3}\right)_{3}{ }^{2-}$ and $\mathrm{MgPuO}{ }_{2}\left(\mathrm{CO}_{3}\right)_{3}{ }^{2-}$ and the data from NEA-TDB. ${ }^{13}$ It is worth noting that the modelling was performed at considerably reduced $\mathrm{Pu}$ concentrations $\left(10^{-9} \mathrm{M}\right)$ and carbonate amount (atmospheric $\mathrm{CO}_{2}(\mathrm{~g})$ equilibrium) as compared to those used in the experiments $\left([\mathrm{Pu}(\mathrm{vI})]=0.35-0.40 \mathrm{mM}\right.$ and $\left.\left[\mathrm{CO}_{3}{ }^{2-}\right]_{\text {initial }}=18 \mathrm{mM}\right)$. At weakly alkaline pH under oxidizing conditions, $\mathrm{CaPuO}_{2}\left(\mathrm{CO}_{3}\right)_{3}{ }^{2-}$ is the dominant aqueous $\mathrm{Pu}(\mathrm{vI})$ species and the apparent $\mathrm{Pu}(\mathrm{vI} / \mathrm{v})$ Nernstian potential is shifted toward a less positive value, which suggests a slight but further redox stabilization of $\mathrm{Pu}(\mathrm{vI})$. As a consequence of the formation of $\mathrm{CaPuO}_{2}\left(\mathrm{CO}_{3}\right)_{3}{ }^{2-}$, the effect of $\mathrm{PuO}_{2}\left(\mathrm{CO}_{3}\right)_{2}{ }^{2-}$, which was expected to be the major $\mathrm{Pu}(\mathrm{vI})$ species in previous work, ${ }^{5,11,12}$ would be weakened in the presence of calcium at environmental (millimolar) concentrations. Based on the aqueous $\mathrm{Pu}(\mathrm{vI})$ speciation (Fig. $3 \mathrm{~b}$ ), the predominance of $\mathrm{CaPuO}_{2}\left(\mathrm{CO}_{3}\right)_{3}{ }^{2-}$ and a correspondingly decreased amount of $\mathrm{PuO}_{2}\left(\mathrm{CO}_{3}\right)_{2}{ }^{2-}$ are expected in natural waters such as rainwater, groundwater, and seawater. In addition, the strong ternary complexation could increase $\mathrm{Pu}(\mathrm{vI})$ solubility up to approximately six times at $\mathrm{pH}$ 7.5-9.0 (ESI, Fig. S7†).

Table 1 Equilibrium constants $(\log K)$ of $\mathrm{Mg}^{2+} / \mathrm{Ca}^{2+}$ complexation with $\mathrm{PuO}_{2}\left(\mathrm{CO}_{3}\right)_{3}{ }^{4-}$

$\log K$

\begin{tabular}{|c|c|c|c|}
\hline Reactions & $I=0.1 \mathrm{M} \mathrm{H} / \mathrm{NaClO}_{4}$ & $I=0 \mathrm{M}$ infinite dilution & Ref. \\
\hline
\end{tabular}

${ }^{a}$ Present work. ${ }^{b}$ Corrected by using the Davies equation. ${ }^{43}$ 

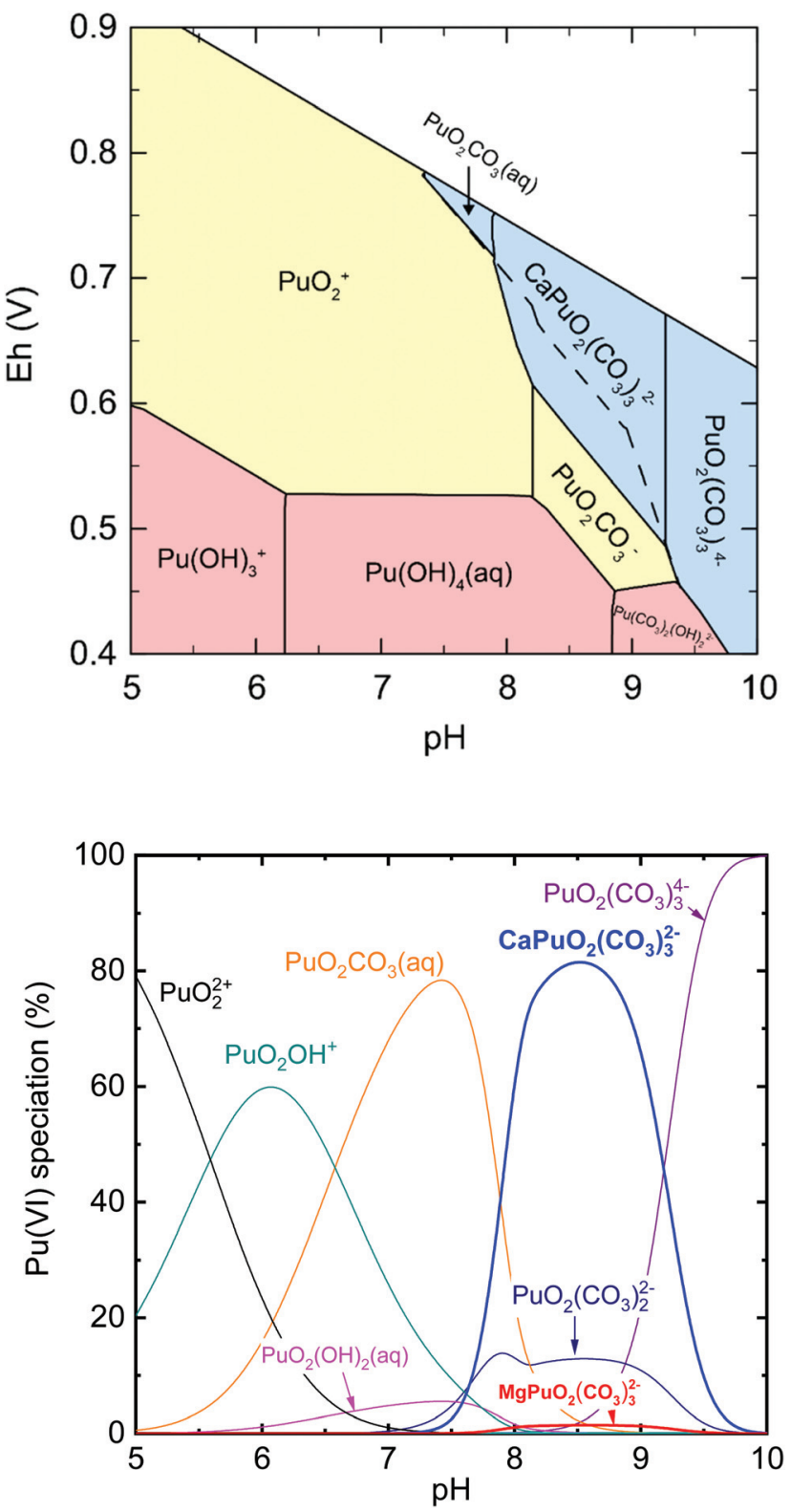

Fig. 3 Environmental implications of the formation of $\mathrm{CaPuO}_{2}\left(\mathrm{CO}_{3}\right)_{3}{ }^{2-}$ and $\mathrm{MgPuO}_{2}\left(\mathrm{CO}_{3}\right)_{3}{ }^{2-}\left([\mathrm{Pu}]=1 \times 10^{-9} \mathrm{M},\left[\mathrm{Ca}^{2+}\right]=\left[\mathrm{Mg}^{2+}\right]=1 \mathrm{mM}\right.$, in equilibrium with $p_{\mathrm{CO} 2(\mathrm{~g})}=10^{-3.4} \mathrm{~atm}$, at $25{ }^{\circ} \mathrm{C}$ and infinite dilution). (a) Calculated Pourbaix $\left(E_{\mathrm{h}}-\mathrm{pH}\right)$ diagram of aqueous plutonium species. The dashed line represents the boundary of apparent $\mathrm{Pu}(\mathrm{vi} / \mathrm{v})$ Nernstian potential in the absence of $\mathrm{Ca}^{2+}$ and $\mathrm{Mg}^{2+}$. (b) Calculated aqueous $\mathrm{Pu}(\mathrm{vI})$ species distribution. The abrupt change at $\mathrm{pH} 8.1$ occurs due to the solubility of $\mathrm{Ca}^{2+}$ in the carbonate system. For the details of calculation, see section 2.4 .

\section{Conclusions}

The complexations of aqueous plutonyl(vi) carbonate species with $\mathrm{Ca}^{2+}$ and $\mathrm{Mg}^{2+}$ were identified for the first time using visNIR absorption spectroscopy. In $\mathrm{Ca}^{2+}$ or $\mathrm{Mg}^{2+}$ titrations, a characteristic absorption signal at $808 \mathrm{~nm}$, which was not observed in the plutonyl carbonate system, i.e. $\mathrm{PuO}_{2}\left(\mathrm{CO}_{3}\right)_{2}{ }^{2-}$ and $\mathrm{PuO}_{2}\left(\mathrm{CO}_{3}\right)_{3}{ }^{4-}$, appears and it is a clear indication of the ternary complexation of plutonyl(vi)carbonate with alkaline earth metals. The results of vis-NIR absorption spectroscopy evidently show that $\mathrm{Ca}^{2+}$ interacts with $\mathrm{PuO}_{2}\left(\mathrm{CO}_{3}\right)_{3}{ }^{4-}$ rather than with $\mathrm{PuO}_{2}\left(\mathrm{CO}_{3}\right)_{2}{ }^{2-}$, and the results of slope analysis provide the stoichiometric number of $\mathrm{Ca}^{2+}$ complexing with $\mathrm{PuO}_{2}\left(\mathrm{CO}_{3}\right)_{3}{ }^{4-}$ as 1 , indicating the formation of $\mathrm{MPuO}_{2}\left(\mathrm{CO}_{3}\right)_{3}{ }^{2-}$ $\left(\mathrm{M}=\mathrm{Ca}^{2+}\right.$ and $\left.\mathrm{Mg}^{2+}\right)$. Based on the results of spectrophotometric titration and the correction of ionic strength using the Davies equation, the formation constants of $\mathrm{CaPuO}_{2}\left(\mathrm{CO}_{3}\right)_{3}{ }^{2-}$ and $\mathrm{MgPuO}_{2}\left(\mathrm{CO}_{3}\right)_{3}{ }^{2-}$ from $\mathrm{PuO}_{2}\left(\mathrm{CO}_{3}\right)_{3}{ }^{4-}$ are determined to be $\log K^{\circ}=6.05 \pm 0.50$ and $4.29 \pm 0.18$, respectively.

The prediction of the environmental behaviour of plutonium based on the geochemical calculation considering $\mathrm{MPuO}_{2}\left(\mathrm{CO}_{3}\right)_{3}{ }^{2-}$ suggests that $\mathrm{CaPuO}_{2}\left(\mathrm{CO}_{3}\right)_{3}{ }^{2-}$ would be the most predominant $\mathrm{Pu}(\mathrm{vI})$ species and increase $\mathrm{Pu}(\mathrm{vI})$ solubility in the natural waters. It may also affect the redox property of plutonium and stabilize $\mathrm{Pu}$ in the hexavalent state by strong complexation. Ternary $\mathrm{Mg}^{2+} / \mathrm{Ca}^{2+}-\mathrm{PuO}_{2}\left(\mathrm{CO}_{3}\right)_{3}{ }^{4-}$ complexes can enhance $\mathrm{Pu}$ migration in aqueous systems under oxidizing conditions such as groundwater and seawater containing abundant calcium, magnesium, and carbonate.

\section{Conflicts of interest}

There are no conflicts to declare.

\section{Acknowledgements}

This work was supported by a grant from the Nuclear R\&D Program of the National Research Foundation of Korea funded by the Korean Ministry of Science and ICT (grant codes: 2016M2B2B1945252 and 2017M2A8A5014719).

\section{Notes and references}

1 E. P. Hardy, P. W. Krey and H. L. Volchok, Nature, 1973, 241, 444-445.

2 D. M. Nelson and M. B. Lovett, Nature, 1978, 276, 599-601.

3 K. J. Cantrell and A. R. Felmy, Plutonium and americium geochemistry at Hanford: a site wide review, Report PNNL-21651, Pacific Northwest National Lab. (PNNL), Richland, WA (United States), 2012.

4 D. L. Clark, The chemical complexities of plutonium, NM, 2000.

5 A. E. Hixon and B. A. Powell, Environ. Sci.: Processes Impacts, 2018, 20, 1306-1322.

6 R. Fukai, A. Yamato, M. Thein and H. Bilinski, Geochem. J., 1987, 21, 51-57.

7 G. R. Choppin and A. Morgenstern, in Radioactivity in the Environment, ed. A. Kudo, Elsevier, Amsterdam, 2001, vol. 1, pp. 91-105.

8 G. R. Choppin and P. J. Wong, Aquat. Geochem., 1998, 4, 77-101.

9 R. P. Larsen and R. D. Oldham, Science, 1978, 201, 1008-1009. 
10 I. Pashalidis, J. I. Kim, C. Lierse and J. C. Sullivan, Radiochim. Acta, 1993, 60, 99.

11 K. Maher, J. R. Bargar and G. E. Brown, Inorg. Chem., 2013, 52, 3510-3532.

12 S. D. Reilly, W. Runde and M. P. Neu, Geochim. Cosmochim. Acta, 2007, 71, 2672-2679.

13 R. Guillaumont, T. Fanghänel, J. Fuger, I. Grenthe, V. Neck, D. A. Palmer and M. H. Rand, Chemical thermodynamics, in Update on the chemical thermodynamics of uranium, neptunium, plutonium, americium and technetium, Elsevier, Amsterdam, 2003, vol. 5.

14 G. Bernhard, G. Geipel, V. Brendler and H. Nitsche, Radiochim. Acta, 1996, 74, 87-91.

15 S. N. Kalmykov and G. R. Choppin, Radiochim. Acta, 2000, 88, 603-606.

16 G. Bernhard, G. Geipel, T. Reich, V. Brendler, S. Amayri and H. Nitsche, Radiochim. Acta, 2001, 89, 511-518.

17 W. Dong and S. C. Brooks, Environ. Sci. Technol., 2006, 40, 4689-4695.

18 W. Dong and S. C. Brooks, Environ. Sci. Technol., 2008, 42, 1979-1983.

19 G. Geipel, S. Amayri and G. Bernhard, Spectrochim. Acta, Part A, 2008, 71, 53-58.

20 J.-Y. Lee and J.-I. Yun, Dalton Trans., 2013, 42, 9862-9869.

21 F. Endrizzi and L. Rao, Chem. - Eur. J., 2014, 20, 1449914506.

22 J.-Y. Lee, M. Vespa, X. Gaona, K. Dardenne, J. Rothe, T. Rabung, M. Altmaier and J.-I. Yun, Radiochim. Acta, 2017, 105, 171-185.

23 Y. Jo, A. Kirishima, S. Kimuro, H.-K. Kim and J.-I. Yun, Dalton Trans., 2019, 48, 6942-6950.

24 Y. Jo, H.-K. Kim and J.-I. Yun, Dalton Trans., 2019, 48, 14769-14776.

25 C. Shang and P. E. Reiller, Dalton Trans., 2020, 49, 466481.

26 Z. Zheng, T. K. Tokunaga and J. Wan, Environ. Sci. Technol., 2003, 37, 5603-5608.

27 P. M. Fox, J. A. Davis and J. M. Zachara, Geochim. Cosmochim. Acta, 2006, 70, 1379-1387.

28 B. D. Stewart, M. A. Mayes and S. Fendorf, Environ. Sci. Technol., 2010, 44, 928-934.

29 S. C. Brooks, J. K. Fredrickson, S. L. Carroll, D. W. Kennedy, J. M. Zachara, A. E. Plymale, S. D. Kelly, K. M. Kemner and S. Fendorf, Environ. Sci. Technol., 2003, 37, 1850-1858.

30 J. Wan, T. K. Tokunaga, E. Brodie, Z. Wang, Z. Zheng, D. Herman, T. C. Hazen, M. K. Firestone and S. R. Sutton, Environ. Sci. Technol., 2005, 39, 6162-6169.
31 B. D. Stewart, P. S. Nico and S. Fendorf, Environ. Sci. Technol., 2009, 43, 4922-4927.

32 C. Liu, J. M. Zachara, L. Zhong, S. M. Heald, Z. Wang, B.-H. Jeon and J. K. Fredrickson, Environ. Sci. Technol, 2009, 43, 4928-4933.

33 E. L. Tullborg, J. Suksi, G. Geipel, L. Krall, L. Auqué, M. Gimeno and I. Puigdomenech, Procedia Earth Planet. Sci., 2017, 17, 440-443.

34 B. Reeves, M. R. Beccia, P. L. Solari, D. E. Smiles, D. K. Shuh, C. Berthomieu, D. Marcellin, N. Bremond, L. Mangialajo, S. Pagnotta, M. Monfort, C. Moulin and C. Den Auwer, Environ. Sci. Technol., 2019, 53, 79747983.

35 H.-R. Cho, Y.-S. Youn, E. C. Jung and W. Cha, Dalton Trans., 2016, 45, 19449-19457.

36 E. C. Jung and H.-R. Cho, in The delivery of nanoparticles, ed. A. A. Hashim, InTech, Rijeka, 2012.

37 P. Gans, A. Sabatini and A. Vacca, Talanta, 1996, 43, 17391753.

38 J. W. Ball and D. K. Nordstrom, WATEQ4F - User's manual with revised thermodynamic data base and test cases for calculating speciation of major, trace and redox elements in natural waters, U.S. Geological Survey, 1991.

39 L. Ciavatta, Ann. Chim., 1980, 70, 551-567.

40 I. Grenthe, F. Mompean, K. Spahiu and H. Wanner, TDB-2: guidelines for the extrapolation to zero ionic strength, OECD Nuclear Energy Agency, Issy-les-Moulineaux, 2013.

41 J.-C. Alexandre, N. Dacheux and J. Aupiais, Radiochim. Acta, 2018, 106, 801.

42 T. Thoenen, W. Hummel, U. Berner and E. Curti, The PSI/ Nagra chemical thermodynamic database 12/07, Paul Scherrer Institut, Villigen PSI, Switzerland, 2014.

43 C. W. Davies, Ion association, Butterworths, Washington D. C., 1962.

44 D. L. Parkhurst and C. Appelo, Description of input and examples for PHREEQC version 3: a computer program for speciation, batch-reaction, one-dimensional transport, and inverse geochemical calculations, U.S. Geological Survey, 2013.

45 J. S. Martinez, E.-F. Santillan, M. Bossant, D. Costa and M.-E. Ragoussi, Appl. Geochem., 2019, 107, 159-170.

46 D. G. Kinniburgh and D. M. Cooper, PhreePlot-Creating graphical output with PHREEQC, http://www.phreeplot.org/, version updated 4 May 2020.

47 P. G. Varlashkin, G. M. Begun and J. R. Peterson, Radiochim. Acta, 1984, 35, 211.

48 D. T. Reed, Radiochim. Acta, 1994, 66-67, 95. 